\title{
Natural history of ctenophores in the Resolute Passage area of the Canadian High Arctic with special reference to Mertensia ovum*
}

\author{
Timothy D. Siferd ${ }^{1}$, Robert J. Conover ${ }^{2}$ \\ ${ }^{1}$ Department of Fisheries and Oceans, Central and Arctic Region, Freshwater Institute, 501 University Crescent, Winnipeg, \\ Manitoba, Canada R3T 2N6 \\ ${ }^{2}$ Department of Fisheries and Oceans, Biological Sciences Branch, Bedford Institute of Oceanography, PO Box 1006 , \\ Dartmouth, Nova Scotia, Canada B2Y 4A2
}

\begin{abstract}
The natural history of ctenophores from the Resolute Passage area of the Canadian High Arctic was examined in 1985 and 1986. The seasonal abundance of 3 ctenophore species, Mertensia ovum, Beroe cucumis, and Bolinopsis infundibulum, are reported. M. ovum was by far the most abundant, accounting for $88.9 \%$ of all ctenophores collected, and because of its abundance received the most study. The $M$. ovum population developed similarly in both years reaching a maximum abundance of $911 \mathrm{~m}^{-2}$ in early June 1986. The lipofuscin age-pigment technique suggested that $M$. ovum can live for at least 3 уг. Gut contents showed $M$. ovum to be an opportunistic feeder, but the copepods Pseudocalanus acuspes, Calanus glacialis and C. hyperboreus and the amphipod Parathemisto libellula formed most of the diet. $M$. ovum was estimated to consume between 4 and $10 \% \mathrm{~d}^{-1}$ of the standing crop of macrozooplankton in Resolute Passage.
\end{abstract}

\section{INTRODUCTION}

In the marine ecosystem, gelatinous predators appear to be important regulators of prey populations and control their own populations by preying on each other and their own offspring (Kremer 1976, Reeve et al. 1978, Greve \& Reiners 1988, Purcell 1991). They feed at all levels in the food web, thereby acting both as predators of and potential competitors with fish and other zooplankton (Möller 1980, Shushkina \& Musayeva 1983, Purcell \& Grover 1990). These predators can have daily rations exceeding $1000 \%$ of their body weight which can be converted into rapid growth rates (Reeve et al. 1978). High feeding rates, combined with rapid growth, show that control of zooplankton populations is within their capabilities (Greve \& Reiners 1988). Control of copepod population growth keeps phytoplankton populations from being overgrazed (Greve \& Reiners 1988) and algal growth may be enhanced by the return

\footnotetext{
- Contribution Number 16 from the Resolute Bay Marine Laboratory
}

of dissolved nutrients through excretion into the water column (Biggs 1977, Park \& Carpenter 1987).

In the Canadian Arctic, a single ctenophore species, Mertensia ovum, makes up 60 to $95 \%$ of the total calories in the macrozooplankton community (Percy \& Fife 1985). However, until fairly recently the ecology of this important predator had not been investigated. Percy (1989) found a population in Frobisher Bay that varied little in abundance over the year, although it was considerably smaller than populations offshore in Baffin Bay (Huntley et al. 1983, Percy 1989). Swanberg \& Båmstedt (1991) have recently modelled the predation potential of $M$. ovum in the Barents Sea, estimating that this population could consume between 1 and $5 \% \mathrm{~d}^{-1}$ of the copepods in the water column.

Here, we examine the role of ctenophores in a high arctic marine ecosystem, first by giving a brief account of the natural history of the ctenophores in Resolute Passage (Northwest Territories, Canada), and second by describing the feeding ecology of the dominant gelatinous zooplankter, the cydippid ctenophore Mertensia ovum 


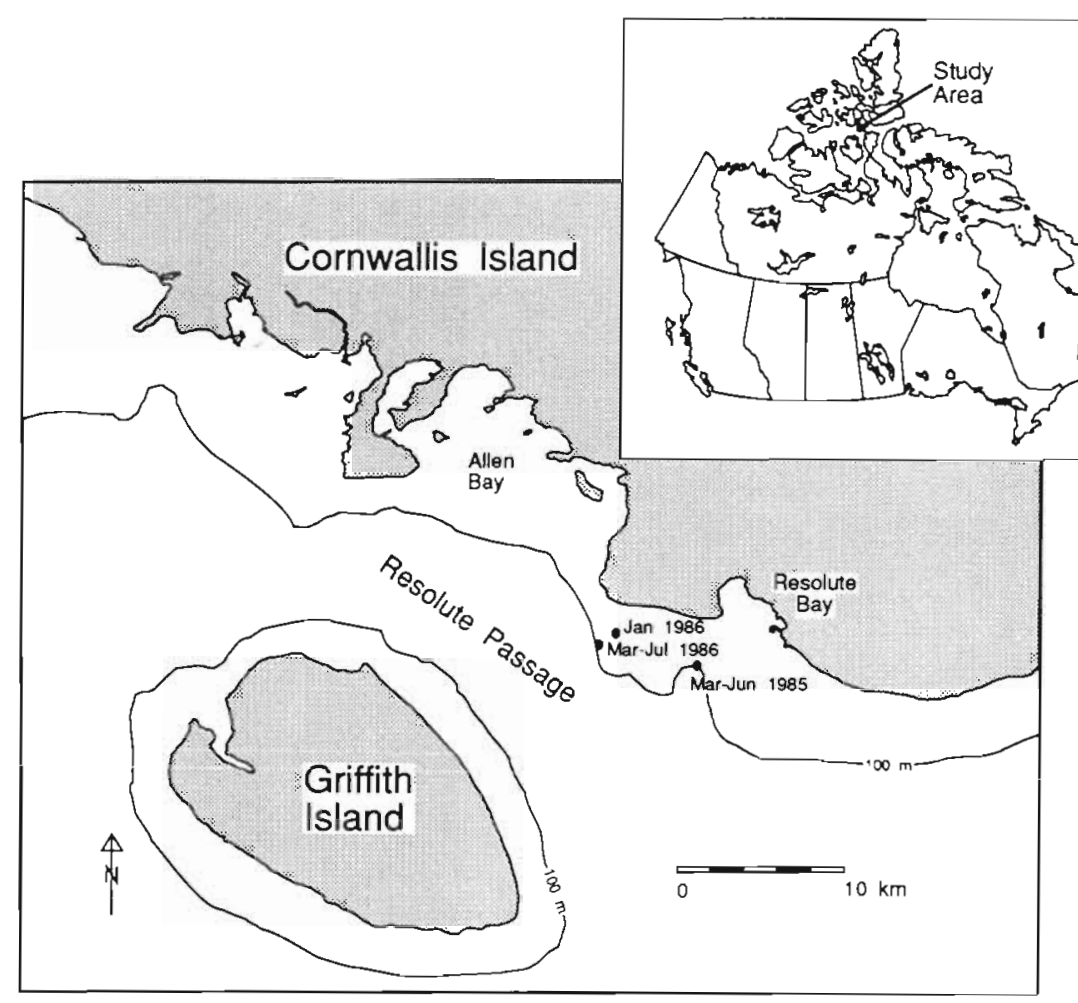

\section{STUDY AREA AND METHODS}

Study area. Resolute Passage $\left(74^{\circ} 40^{\prime} \mathrm{N}, 95^{\circ} 10^{\circ} \mathrm{W}\right)$ is located in the central Canadian Arctic Archipelago and separates southwest Cornwallis Island from Griffith Island (Fig. 1). The passage has a maximum depth of $168 \mathrm{~m}$, but water entering from the west must pass over a sill at a depth of $125 \mathrm{~m}$. The physical oceanography of this section of the Northwest Passage is complex. Water from several different sources can enter the passage depending on local meteorological and tidal conditions (Prinsenberg \& Bennett 1987). Peak flow in the water column can reach 40 to $50 \mathrm{~cm} \mathrm{~s}^{-1}$ during spring tides (Prinsenberg \& Bennett 1987, 1989), but the mean residual current moves water eastward toward Lancaster Sound at about $6 \mathrm{~cm}$ $\mathrm{s}^{-1}$ (Prnsenberg \& Bennett 1987). Land-fast sea-ıce up to 2 m thick is a persistent feature in Resolute Passage. The Passage is normally frozen over from November to JuIy. Once frozen, the ice sheet is usually quite solid with few or no leads.

Sampling. Ice season: Sampling during the fast-ice season was conducted dunng 3 periods: 20 March to 12 June 1985,8 to 18 January 1986,20 March to 8 July 1986. The position of each camp (Fig 1) was influenced by the avallabiluty of relatively smooth ice and sufficient water depth. A large, unformly flat pan of ice as close to the $100 \mathrm{~m}$ contour as possible was
Fig. 1 Sampling locations occupied in the study area during the field seasons of 1985 and 1986

selected as a sampling site to minimize turbulence in sub-ice waters. Water depths at the sites varied from 86 to $99 \mathrm{~m}$.

A heated portable shelter (Parcol, Panabec Ltd, Montreal, PQ. Canada), with a diesel-generated power source was erected over a $2 \times 1.5 \mathrm{~m}$ hole cut in the sea-ice. Samples were collected with a $1 \mathrm{~m}$ diameter, opening/closing, nested, double net $(3 \mathrm{~mm}$ inner and $202 \mu \mathrm{m}$ outer net) specially rigged for horizontal 'towing' through sea-ice using the tidal currents to stream the net (Siferd \& Conover 1992). Approximately biweekly horizontal samples were taken at 2,10 and additional $10 \mathrm{~m}$ intervals to the nearest interval above the bottom, considering the bottom of the ice to be zero depth. All horizontal collections were metered to give the volume of water filtered. The duration (ca 15 to $25 \mathrm{~min}$ ) of the tow vaned with current speed so that ca 150 to $200 \mathrm{~m}^{3}$ of water was sampled. Since currents were necessary for sampling, collections were made opportunistically without regard to tume of day or tidal stage. However, an entire set of tows from top to bottom was attempted with the tide running in a single direction, either ebb or flood. When this was not possible, the set was completed on the returning tide. Inner course-net samples were enumerated as they were removed from the net. Mertensia ovum were removed and individually frozen $\left(-20^{\circ} \mathrm{C}\right)$ for further analyses. Other ctenophores were counted and then discarded; individuals of any species $<3 \mathrm{~mm}$ in diameter and ctenophore eggs were enumerated from a subsample of the outer net sample after preservation in 3 to $4 \%$ formalin.

Open-water season: Open-water samples were collected from a $7 \mathrm{~m}$ vessel for the periods 20 July to 30 August 1985 and all August 1986 near the depth and position of the ice station of that year. Samples were collected at approximately $20 \mathrm{~m}$ depth intervals from the surface to the bottom, using the same double net rigged for towing with a bridle to keep the mouth 
vertical. However, because phytoplankton often clogged the outer, finer, net, only the inner net was towed horizontally to collect large specimens and a choke line was added to close it at depth. The water volume filtered was estimated from a flowmeter suspended at $10 \mathrm{~m}$, assuming net efficiency was $100 \%$. Samples for ctenophores $<3 \mathrm{~mm}$ during the summer were collected at $10 \mathrm{~m}$ intervals from top to bottom with a vertically hauled, $0.5 \mathrm{~m}$ closing net of $202 \mu \mathrm{m}$ mesh. In this paper abundance describes the number of individual ctenophores $\mathrm{m}^{-2}$, assuming a water column of depth to the bottom, and density indicates the number of ctenophores $\mathrm{m}^{-3}$ of water.

Digestion rate. Paired, glass aquaria were constructed to maintain live ctenophores utilizing the principle of the 'Doppelküvette' (Greve 1970) as modified by Bell (1989). Each aquarium had 2 chambers, measuring $90 \times 60 \times 15 \mathrm{~cm}$ (height $\times$ length $\times$ width) and each held ca 801 of water. Each had an airlift pump which circulated the water in a slow clockwise direction. The aquarium was placed in a $225 \mathrm{l}$ polyethylene tank, cooled by water pumped directly from the sea, but, as only about one-quarter of each aquarium was submerged, the equilibrium temperature was 0.0 to $1.5^{\circ} \mathrm{C}$, ca 1.5 to $3^{\circ} \mathrm{C}$ above ambient ( $\mathrm{ca}-1.5^{\circ} \mathrm{C}$ ).

Digestion rate was determined on SCUBA-diveprocured Mertensia ovum. Individuals were collected in $75 \mathrm{~mm}$ diameter $\times 160 \mathrm{~mm}$ PVC tubes closed with rubber stoppers. The tubes were kept in a pail of seawater to help maintain their temperature until they could be transferred to the aquaria, usually within 30 min. Ctenophores were released directly into an aquarium, previously filled with $50 \mu \mathrm{m}$ screened seawater. No more than 3 individuals were placed in one chamber of an aquarium. Ctenophores generally resumed active swimming and extended their tentacles within $15 \mathrm{~min}$ of their release. Specimens were allowed to acclimate for $24 \mathrm{~h}$ prior to experimentation. A 'prey' aquarium was stocked with copepods between 250 and $500 \mu \mathrm{m}$ screened from a net tow. Ctenophores were carefully dipped from the holding tank in a large plastic beaker and placed in the prey aquarium until they were observed to feed. They were then placed in a prey-free aquarium. With larger prey (>1 $\mathrm{mm})$, ctenophores were fed by pipetting individual copepods of known size and species directly to the tentacles. The behavior of the ctenophores was observed and times of ingestion and removal of the tentacle from the mouth noted. Individual ctenophores were removed at $30 \mathrm{~min}$ intervals from 1.5 to $4 \mathrm{~h}$ and frozen $\left(-20^{\circ} \mathrm{C}\right)$ to stop the digestion process.

Later specimens were thawed and prey examined for state of digestion under a dissecting microscope. In early digestion, the copepod body was softened and some appendages might be disarticulated. Moderate digestion showed internal tissue loss and many appendages disarticulated. In late digestion body segments were separated and most of the internal tissue was gone. In extreme digestion only the carapace parts remained. Digestion time was taken as time to extreme digestion. Using the same criteria for digestion in gut contents of net-caught specimens, we found no evidence for net feeding.

Gut contents. All Mertensia ovum collected in the net tows were examined for gut contents. Before thawing a specimen, the polar (oral-aboral) length was measured with calipers. With the aid of a dissecting microscope, prey remains were identified to species or to nearest taxon. Size of prey was estimated with an eyepiece micrometer using prosome length for copepods and total length for other prey species. Prey were subsequently classified into 3 size categories.

Daily ration. Daily ration was calculated from gut contents assuming gut turnover was the reciprocal of digestion rate; prey were categorized into large, medium, small and unidentifiable size classes. Feeding was assumed to be continuous over $24 \mathrm{~h}$. The average number of prey items consumed per ctenophore per day was calculated as:

$$
T P C=\sum_{P C=1}^{4} \frac{A N P C \times 24}{S D T},
$$

where $T P C=$ total prey consumed summed over all size classes; $P C=$ prey size class (small, medium, large, and unidentified); $A N P C=$ average number of prey in the size class per ctenophore; and $S D T=$ size-specific digestion time (Bajkov 1935). Daily ration was converted into carbon daily ration by summing the sizespecific daily ration multiplied by the mean carbon content for each prey size class (large $0.42 \mathrm{mg} \mathrm{C}$, medium $0.06 \mathrm{mg} C$, small $0.005 \mathrm{mg} \mathrm{C}$, unidentified $0.16 \mathrm{mg} \mathrm{C}_{\text {; }}$ Conover unpubl. data)

Maintenance ration (MR) was calculated from respiration, assuming the respiratory quotient (RQ) was 0.8 (Larson 1987 a, b). Summer and winter respiration rates for Mertensia ovum were estimated from seasonal dry weight/length and weight-specific respiration equations from Percy (1988) and expressed as the percentage of total body carbon. Total body carbon was estimated from regressions of polar length on total body carbon for specimens from 7 April, 12 May, 7 June and 24 June 1986. Body carbon of individual ctenophores was determined with a Perkin-Elmer model $240 \mathrm{~B}$ elemental analyzer.

Determination of Mertensia ovum age classes. M. ovum at $20 \mathrm{~m}$ depth were collected on 6 April and 8 June 1986 for age determination by the lipofuscin age-pigment method (Ettershank 1983, 1984). All 
specimens had been previously thawed, examined for gut contents and then refrozen at $-20^{\circ} \mathrm{C}$. Whole individuals were thawed and rinsed into $15 \mathrm{ml}$ centrifuge tubes with distilled water, frozen and lyophilized. The procedure of Ettershank $(1983,1984)$ was followed except that the samples were not sonicated (Nicol 1987) and $4 \mathrm{ml}$ of the chloroform:methanol mixture was added to extract each sample. Quinine sulphate in $1 \mathrm{~N}$ sulphuric acid was used as the standard. To determine age groups, the fluorescence data were analyzed for polymodal frequency distributions using the methods of Harding (1949).

\section{RESULTS}

Four species of Ctenophora, Mertensia ovum, Beroe cucumis, Bolinopsis infundibulum and Pleurobrachia pileus, were collected in Resolute Passage during this study. $M$. ovum accounted for $88.9 \%$ of all ctenophores collected and $71.4 \%$ of all gelatinous zooplankton (ctenophores, hydromedusae and scyphomedusae) caught. Beroe cucumis made up $11 \%$ and Bolinopsis infundibulum $0.1 \%$ of the ctenophores collected. Only a single specimen of $P$. pileus was collected.

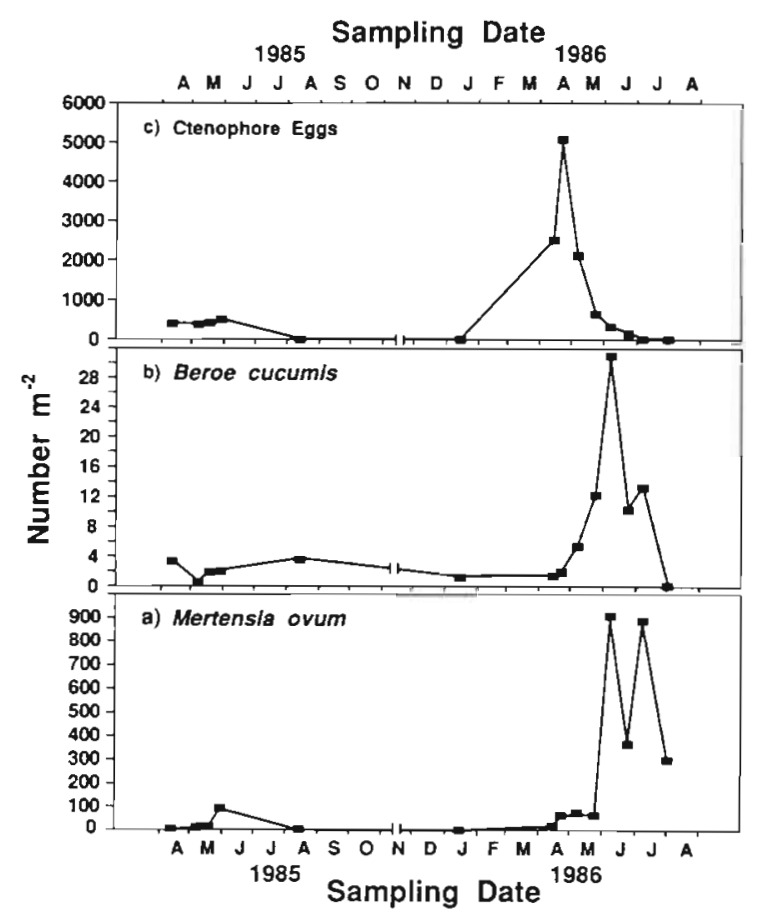

Fig. 2. Seasonal population abundance of the ctenophores (a) Mertensia ovum and (b) Beroe cucumis, and (c) ctenophore eggs

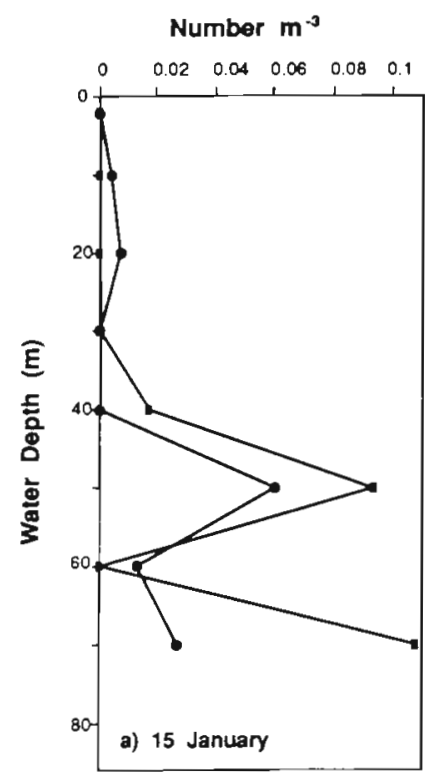

- Mertensla ovum

- Beroe cucum/s
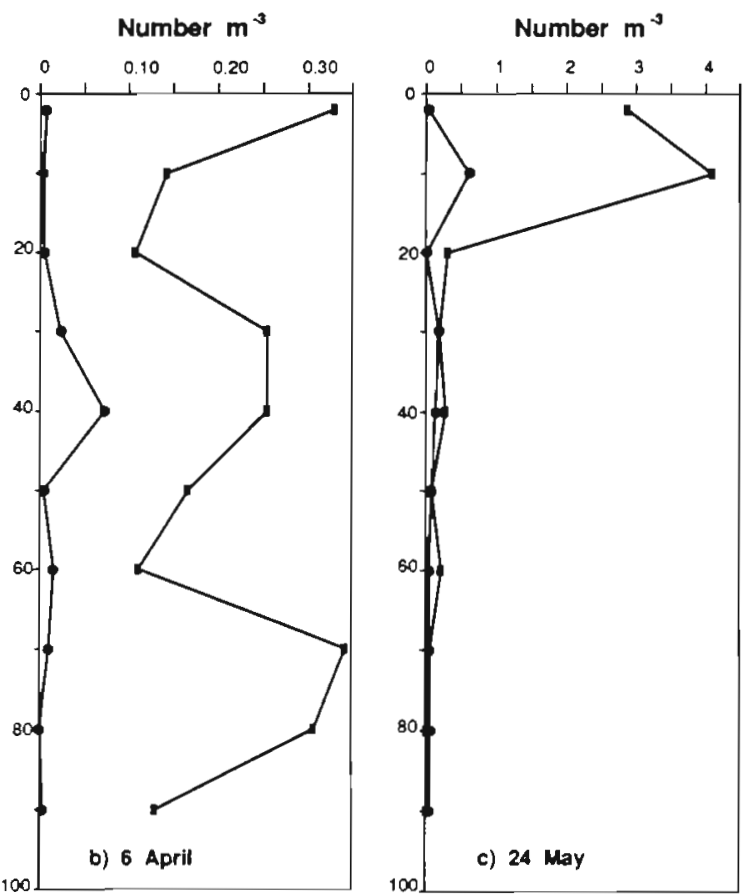

Fig. 3. Mertensia ovum and Beroe cucumis. Depth distributions of the 2 dominant ctenophores on (a) 15 January 1986, (b) 6 April 1986 and (c) 24 May 1986. The time periods were selected to illustrate changes in depth distributions through the year 


\section{Seasonal abundance of Mertensia ovum and Beroe cucumis}

In 1985, the population of Mertensia ovum was low with maximum abundance of $94.4 \mathrm{~m}^{-2}$ at the end of May (Fig. 2a). Beroe cucumis numbers peaked in mid August at $3.57 \mathrm{~m}^{-2}$ (Fig. 2b). At the maximum, $M$. ovum had a mean water column density $( \pm \mathrm{SE}$ ) of 1.02 $\pm 0.30 \mathrm{~m}^{-2}$ and $B$. cucumis $0.02 \pm 0.01 \mathrm{~m}^{-2}$. In 1986 ctenophore numbers increased from near zero in January through the spring, reaching a maximum abundance of $911 \mathrm{~m}^{-2}$ during the first week of June for M. ovum (Fig. 2a) and $31.1 \mathrm{~m}^{-2}$ for B. cucumis (Fig. 2b). The corresponding mean density over the entire water column was $12.3 \pm 7.60 \mathrm{~m}^{-3}$ for $M$. ovum and $0.36 \pm 0.13 \mathrm{~m}^{-3}$ for $B$. cucumis. The highest density recorded for $M$. ovum was $70.4 \mathrm{~m}^{-3}$ from the surface waters ( $2 \mathrm{~m}$ ) on 7 June 1986 . B. cucumis at $10 \mathrm{~m}$ depth reached a maximum recorded density of $1.03 \mathrm{~m}^{-3}$ also on 7 June 1986. The yearly mean density for 1985 was $0.35 \pm 0.09 \mathrm{~m}^{-3}$ for $M$. ovum and $0.02 \pm 0.01 \mathrm{~m}^{-3}$ for $B$. cucumis. In 1986 yearly mean density increased to $4.05 \pm 1.29 \mathrm{~m}^{-3}$ for $M$. ovum and $0.10 \pm 0.02 \mathrm{~m}^{-3}$ for B. cucumis.

Although ctenophore abundance differed markedly from 1985 to 1986, the population structure changed in a similar way each year. Beginning in January, with only a small number of large ctenophores (>3 mm) present in the water column, egg numbers began to increase from very low levels early in the year reaching a maximum in late April or early May (Fig. 2c). Egg production then declined rapidly, numbers decreasing by 2 orders of magnitude within 2 mo. Following maximum egg numbers, young ctenophores began to increase, reaching their peak about 1.5 to 2 mo later

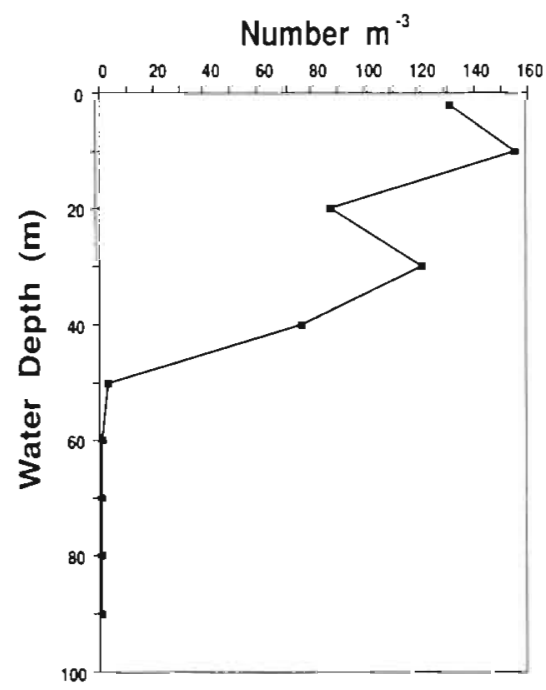

Fig. 4. Depth distribution of ctenophore eggs on 22 April 1986. Time period chosen represents the peak of egg abundance

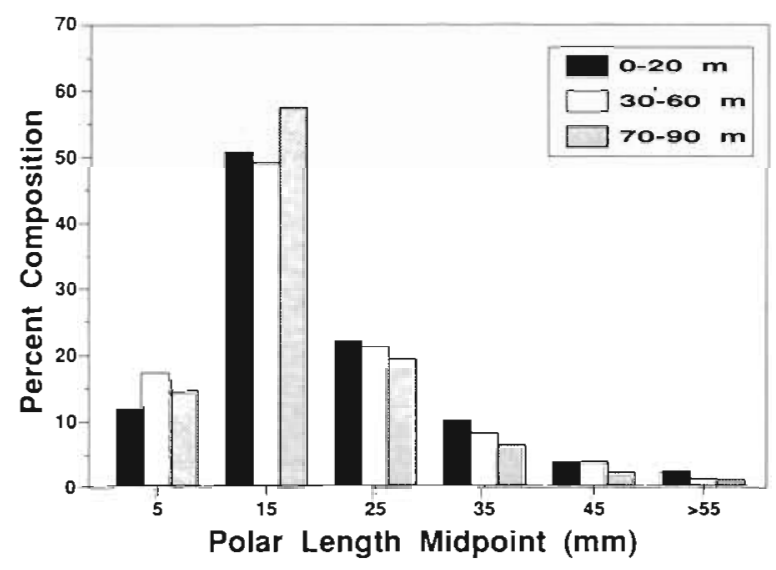

Fig. 5. Mertensia ovum. Percent composition of size classes as a function of water column position in 1986

(Fig. 2a, b). From a mid-summer high densities then declined to a mid-winter low.

The 2 dominant ctenophores had similar vertical distributions throughout the year. In January (Fig. 3a) both ctenophores were concentrated near the bottom; by April (Fig. 3b), they were dispersed throughout the water for a short time; however, for most of the year, both species were concentrated in the upper $20 \mathrm{~m}$, as in May (Fig. 3c). Ctenophore eggs were generally found in the upper $30 \mathrm{~m}$ (Fig. 4). Through 1986, size distributions of Mertensia ovum did not vary significantly with position in the water column (Fig. 5).

Bolinopsis infundibulum occurred at low densities (Fig. 6), but their numbers tended to be highest when Mertensia ovum and Beroe cucumis populations were at their yearly low (Figs. 2a, b \& 6). Maximum abundance for $B$. infundibulum, 12 ind $100 \mathrm{~m}^{-2}$, occurred on 22 April 1986, but highest mean water column density was recorded on 15 January 1986 at $0.2 \pm 0.19$ ind $100 \mathrm{~m}^{-3}$. The mean density for 1986 was $0.06 \pm 0.02$ ind $100 \mathrm{~m}^{-3}$.

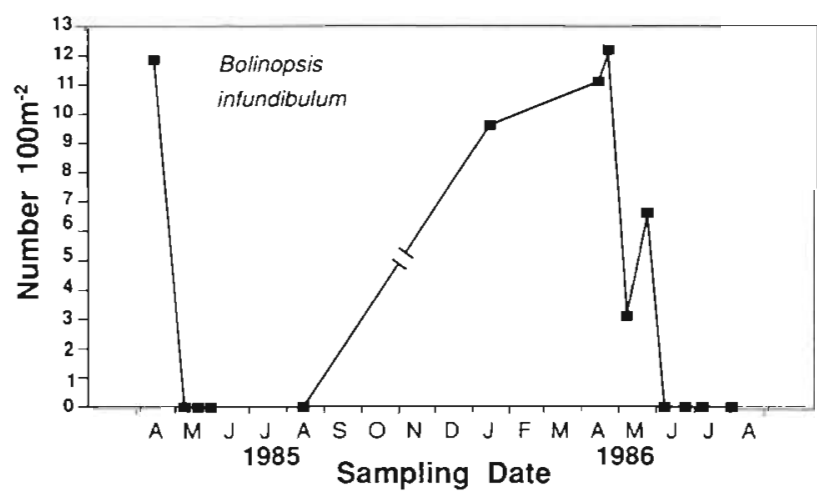

Fig. 6. Bolinopsis infundibulum. Seasonal population abundance 
Table 1. Mertensia ovum. Prey consumed in 1985 and 1986. Number of prey counted with percentage of tatal prey consumed in parentheses. Prey size classes: Large $(\mathrm{L},>5 \mathrm{~mm})$, medium ( $\mathrm{M}, 2-5 \mathrm{~mm})$, small $(\mathrm{S},<2 \mathrm{~mm})$

\begin{tabular}{|c|c|c|c|}
\hline Prey item & $\begin{array}{l}\text { Size } \\
\text { class }\end{array}$ & 1985 & 1986 \\
\hline No of samples & & 587 & 1438 \\
\hline Empty stomachs & & $310(52.8)$ & $1006(70.0)$ \\
\hline No. prey consumed & & 624 & 941 \\
\hline Copepods: & & $564(90.4)$ & $525(55.8)$ \\
\hline Calanus spp. & L & $81(12.9)$ & $11(11.7)$ \\
\hline Pseudocalanus acuspes & $\mathrm{S}$ & $376(60.3)$ & $21(29.9)$ \\
\hline Metridia longa & M & $4(0.4)$ & $27(2.87)$ \\
\hline Euchaetasp. & $\mathrm{L}$ & $2(0.2)$ & $7(0.74)$ \\
\hline Acartia sp. & $\mathrm{S}$ & $4(0.8)$ & 0 \\
\hline Microcalanus sp. & $\mathrm{S}$ & $1(0.6)$ & 0 \\
\hline Oncaea sp. & M & 0 & $2(0.21)$ \\
\hline Oithonasp. & M & $1(0.16)$ & $3(0.32)$ \\
\hline Chiridius sp. & $M$ & 0 & $3(0.32)$ \\
\hline Xanthocalanus sp. & M & $1(0.16)$ & 0 \\
\hline Copepodids & $\mathrm{S}$ & $10(1.6)$ & $2(0.21)$ \\
\hline Copepod nauplii & $\mathrm{S}$ & $24(3.85)$ & $5(0.53)$ \\
\hline Unidentifiable copepods & - & $60(9.62)$ & $85(9.03)$ \\
\hline Other zooplankton: & & $60(9.6)$ & $416(44.2)$ \\
\hline Parathemisto Iibellula & $L$ & $37(5.93)$ & $77(8.18)$ \\
\hline Other amphipods & $\mathrm{L}$ & $16(2.56)$ & $23(2.44)$ \\
\hline Barnacle nauplii & $\mathrm{S}$ & $6(0.96)$ & $308(32.7)$ \\
\hline Isopods a & - & 0 & $6(0.64)$ \\
\hline Ostracods & L & $1(0.16)$ & $2(0.21)$ \\
\hline
\end{tabular}

\section{Feeding ecology of Mertensia ovum}

In 1985, half of the Mertensia ovum examined had empty guts. In 1986, the percentage of empty guts rose to $70.0 \%$ (Table 1). Copepods were numerically domi-

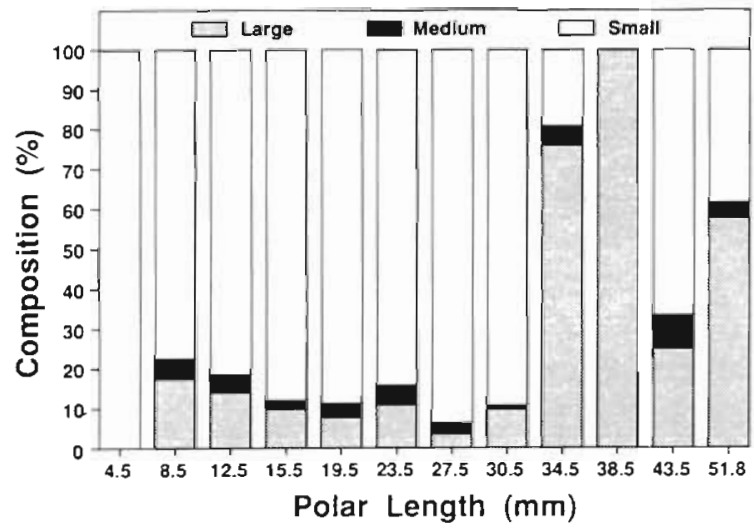

Fig. 7 Mertensia ovum. Percent composition of prey size groups (large, medium, small) consumed by $M$. ovum size groups (mm) in 1986

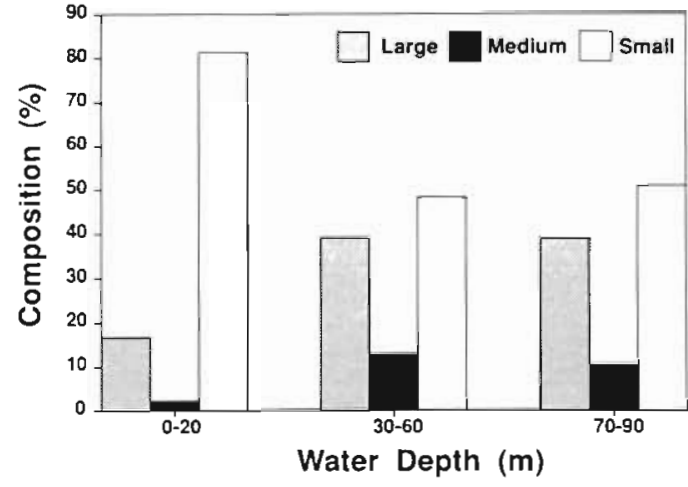

Fig. 8. Mertensia ovum. Percent composition of prey size groups consumed by depth in 1986

nant as prey in both years, except during a brief period in late spring 1986, when large numbers of barnacle nauplii were consumed. Of the copepods, Pseudocalanus acuspes were numerically dominant, comprising 30 to $60 \%$ of the diet. Next most common were Calanus copepods, not easily separated to species in ctenophore guts, forming 12 to $13 \%$ of the prey consumed. The third most common prey were juvenile hyperiid amphipods Parathemisto libellula, forming 6 to $8 \%$ of the diet.

In 1986, small Mertensia ovum tended to consume a greater portion of small prey, while large prey dominated the diet of larger $M$. ovum (Fig. 7). The size composition of the diet also varied with the depth of the predator (Fig. 8). M. ovum in the upper $20 \mathrm{~m}$ fed mostly $(80 \%)$ on small prey. Below $20 \mathrm{~m}$ the size distribution of prey consumed was approximately $50 \%$ large, $10 \%$ medium and $40 \%$ small prey.

\section{Digestion rate}

At temperatures of 0 to $1.5^{\circ} \mathrm{C}$ Mertensia ovum extremely digested $6 \mathrm{~mm}$ (large size class) copepods in $4 \mathrm{~h}, 3$ to $3.5 \mathrm{~mm}$ (medium size class) copepods in $3 \mathrm{~h}$ and $<1 \mathrm{~mm}$ (small size class) copepods in $1.5 \mathrm{~h}$ (Table 2).

\section{Daily ration}

The average daily ration for 1985 was $1.40 \pm 0.14$ (mean $\pm \mathrm{SE}$ ) large, $0.12 \pm 0.04$ medium, $11.4 \pm 1.22$ small and $0.86 \pm 0.15$ unidentified prey. In 1986, the average daily ration was $0.93 \pm 0.10$ large prey items $0.27 \pm 0.04$ medium, $7.04 \pm 0.83$ small and $0.32 \pm 0.04$ unidentified prey items. Converted to carbon, the daily ration was $0.80 \pm 0.06$ and $0.50 \pm 0.04 \mathrm{mg} \mathrm{C}$ during 1985 and 1986 respectively. However, feeding varied 
Table 2. Mertensia ovum. Digestion times when fed various prey size groups. Experiments performed at water temperature of 0 to $1.5^{\circ} \mathrm{C}$. Prey size group in brackets. $\mathrm{n}$ : number of digestion series run

\begin{tabular}{|c|c|c|}
\hline Prey type & $\begin{array}{l}\text { Body length } \\
(\mathrm{mm})\end{array}$ & $\begin{array}{c}\text { Digestion } \\
\text { time }(\mathrm{h})\end{array}$ \\
\hline Calanus hyperboreus & 6 (large) & $4 \quad(n=4)$ \\
\hline Metridia longa & $3-3.5$ (medium) & $3 \quad(n=4)$ \\
\hline Calanus sp. (immature) & 3 (medium) & $3 \quad(n=4)$ \\
\hline Pseudocalanus sp. & $1-1.5$ (small) & $1.5(n=4)$ \\
\hline Unidentified prey & - & $2.8^{d}$ \\
\hline
\end{tabular}

greatly among days and among water depths on the same day (Table 3).

All Mertensia orum consumed more than the maintenance ration estimated from metabolic rates (Fig. 9). Small ctenophores ingested a much higher weightspecific ration than the large ctenophores (Fig. 9a). However, monthly averages of daily ration decreased over the spring of 1986, perhaps indicating increasing competition for food. On the other hand, large $M$. ovum increased their ingestion over the same time period.

Ration in Mertensia ovum was found to be directly affected by their position in the water column regardless of size (Fig. 9b). Small individuals at $10 \mathrm{~m}$ had, on average, double the ingestion ration over those at $80 \mathrm{~m}$, while large ones showed an opposite but weaker trend.

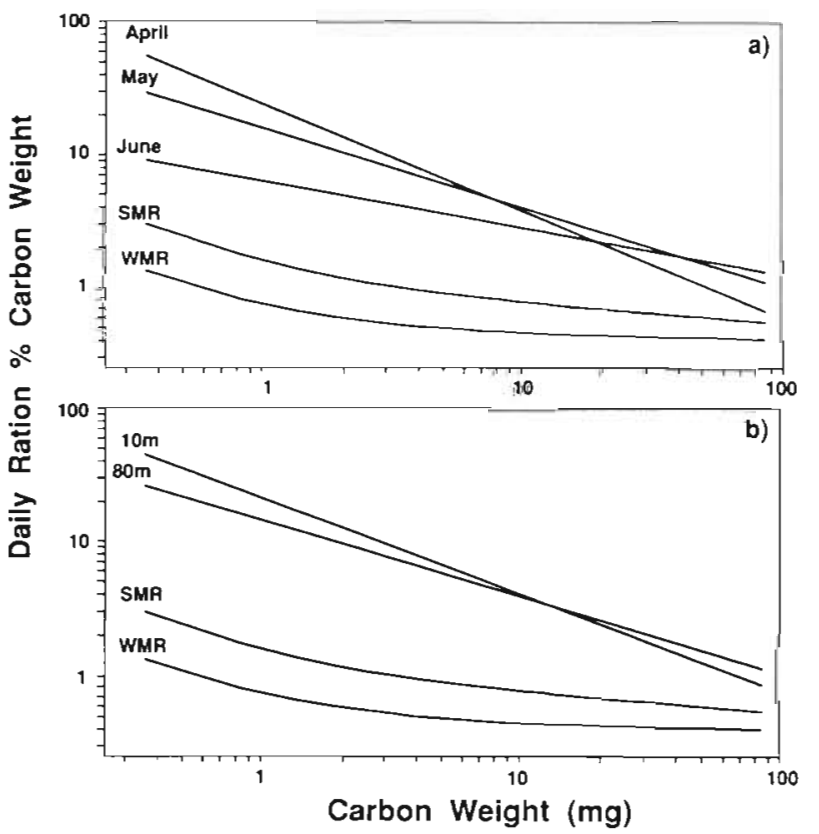

Fig. 9. Mertensia ovum. Least squared regression lines of daily ration expressed as percent total carbon weight of $M$. ovum for (a) April $\left(n=696, r^{2}=0.91\right)$, May $\left(n=507, r^{2}=0.67\right)$ and June $\left(n=235, r^{2}=0.13\right) 1986$, and (b) at $10 \mathrm{~m}(\mathrm{n}=338$, $\left.r^{2}=0.82\right)$ and $80 \mathrm{~m}\left(\mathrm{n}=294, \mathrm{r}^{2}=0.68\right)$. Estimates of summer (SMR) and winter (WMR) maintenance rations (based on metabolic rates of Percy 1988) are expressed as \% total body carbon for comparison

Table 3. Mertensia ovum. Ingestion rates on various dates and at various depths for the different prey classes in 1985 and 1986.

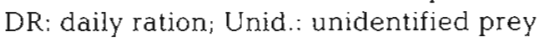

\begin{tabular}{|c|c|c|c|c|c|c|}
\hline \multirow[t]{2}{*}{ Date } & \multirow{2}{*}{$\begin{array}{l}\text { Depth } \\
(\mathrm{m})\end{array}$} & \multirow{2}{*}{$\begin{array}{c}\mathrm{DR} \\
\left(\mathrm{mg} \mathrm{C} \mathrm{d} \mathrm{d}^{-1} \text { ind } .^{-1}\right)\end{array}$} & \multicolumn{4}{|c|}{ Prey size ingested (no. prey $\mathrm{d}^{-1}$ ) } \\
\hline & & & Large & Medium & Small & Unid. \\
\hline \multicolumn{7}{|l|}{1985} \\
\hline All days & $0-99$ & 0.72 & 1.43 & 0.10 & 12.1 & 0.28 \\
\hline All days & $\geq 30$ & 0.37 & 0.73 & 0.09 & 10.1 & 0.35 \\
\hline All days & $30-60$ & 0.65 & 1.37 & 0.10 & 3.86 & 0.31 \\
\hline All days & $\geq 60$ & 0.82 & 1.90 & 0.19 & 1.46 & 0.31 \\
\hline$<18$ May & $0-99$ & 0.49 & 0.87 & 0.05 & 9.42 & 0.55 \\
\hline$>18$ May & $0-99$ & 0.95 & 2.20 & 0.18 & 2.77 & 0.00 \\
\hline 14 May & $0-99$ & 1.63 & 3.49 & 0.56 & 24.9 & 0.00 \\
\hline 22 May & 2 & 0.81 & 0.95 & 0.00 & 14.9 & 0.52 \\
\hline 27-28 May & 2 & 0.37 & 0.56 & 0.00 & 10.1 & 0.15 \\
\hline \multicolumn{7}{|l|}{1986} \\
\hline All days & $0-99$ & 0.51 & 0.91 & 0.18 & 6.73 & 0.00 \\
\hline 24 April & 10 & 0.72 & 1.51 & 0.07 & 0.29 & 0.46 \\
\hline 24 April & 80 & 0.40 & 0.76 & 0.45 & 0.34 & 0.34 \\
\hline 12 May & 10 & 0.83 & 1.40 & 0.00 & 10.9 & 1.15 \\
\hline $12 \mathrm{May}$ & 70 & 0.42 & 0.73 & 0.11 & 5.05 & 0.51 \\
\hline $14 \mathrm{May}$ & 70 & 0.61 & 1.31 & 0.61 & 3.31 & 0.00 \\
\hline 8 June & $12-20$ & 0.61 & 0.98 & 0.23 & 35.6 & 0.00 \\
\hline
\end{tabular}




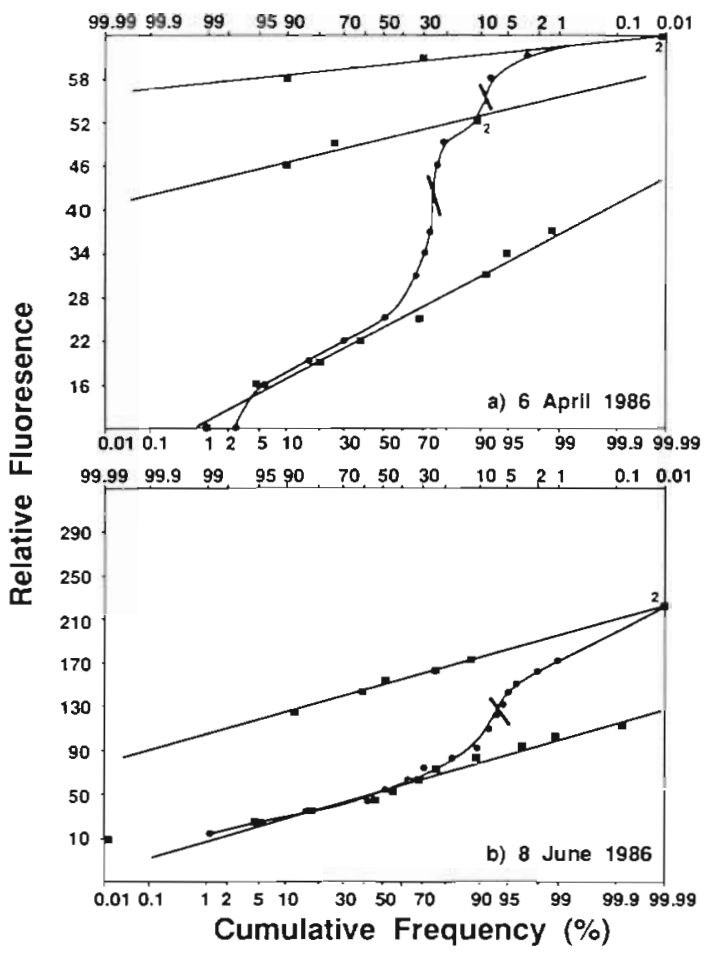

Fig. 10. Mertensia ovum. (•): Probability plot of frequency data based on the relative fluorescence of lipofuscin contained in specimens collected from $20 \mathrm{~m}$ on (a) 6 April 1986 $(\mathrm{n}=36)$ and (b) 8 June $1986(\mathrm{n}=99)$. Heavy bar indicates an inflection point in the curve. (-): Resolved normal modes making up the sample; (2): circle and square occupy same point

\section{Mertensia ovum age classes}

Lipofuscin data for 6 April 1986 clearly show 2 inflection points in the initial plot (Fig. 10a). Therefore, 3 distinct age groups are believed to be present. The sample from 8 June 1986, however, showed only 1 inflection point (Fig. 10b), suggesting 2 age groups only in this sample. Probability plots of size-frequency information from polar length of Mertensia ovum showed only 2 modes for each date, however.

\section{DISCUSSION}

\section{Seasonal distribution of Mertensia ovum and the factors affecting their abundance}

Mertensia ovum in Resolute Passage showed a similar seasonal pattern each year. Beginning with a low overwintering population, numbers peaked in spring and then decreased toward winter levels during the summer and autumn. A similar seasonal pattern of abundance has been shown for ctenophore species from temperate water locations. Pleurobrachia pileus from the Dutch Wadden Sea (van der Veer \& Sadee 1984) and $P$. bachei from Saanich Inlet (Larson 1986a) both exhibit similar spring population peaks.

In sharp contrast with Resolute Passage, Mertensia ovum from Frobisher Bay showed no marked seasonal change in abundance (Percy 1989). There the population-mean abundance was only $3.4 \mathrm{~m}^{-2}$ $\left(0.07 \mathrm{~m}^{-3}\right)$ and the maximum abundance $\mathrm{ca} 25 \mathrm{~m}^{-2}$ in the upper $50 \mathrm{~m}$ of a water column up to $600 \mathrm{~m}$ deep. In Davis Strait, Huntley et al. (1983) reported a mean abundance of $M$. ovum of $1.03 \mathrm{~m}^{-3}$ during 7 cruises between April 1977 and May 1978, an order of magnitude higher than in Frobisher Bay and one-third of the 1985 concentration in Resolute Passage. In 1986, Resolute Passage concentrations were 4 times those in Davis Strait and 60 times those in Frobisher Bay. Apparently conditions in Frobisher Bay prevent $M$. ovum from developing abundances as high as those seen outside the bay. These studies and our data demonstrate that there can be large variability in $M$. ovum abundance over the Arctic.

Rapid changes in abundance are characteristic of gelatinous zooplankton populations (Kremer \& Nixon 1976, van der Veer \& Sadee 1984, Larson 1986a). Such changes also occur in Resolute Passage. In a 2 wk span between 24 May and 7 June 1986 the mean abundance of Mertensia ovum in the water column increased by $150 \%$. This peak abundance was nearly 3 orders of magnitude greater than the mean overwintering population. In the surface waters, numbers increased by $245 \%$ during the same period, a change in population rivalling those reported from southern temperate waters (Kremer \& Nixon 1976, van der Veer \& Sadee 1984).

Spawning of ctenophores can be prolonged, but tends to have a peak period; some temperate species spawn year round (Pianka 1974). Although ctenophore eggs can be found in Resolute Passage over most of the year, large numbers are found only between April and June. For the remainder of the year spawning appears to be nil. The co-occurrence of Mertensia ovum and Beroe cucumis and the restricted period of high egg abundance suggest nearly simultaneous spawning.

\section{Factors affecting Mertensia ovum abundance}

Population dynamics of zooplankton determined from sampling from a single location situated in a complex hydrological environment can lead to inaccurate conclusions. The change in abundance of a species at a given site may not have anything to do with biological processes, but rather may be a consequence of an exchange of water mass containing different populations (Schneider 1987) 
During the ice season, the usual easterly current in Barrow Strait/Resolute Passage produces an upwelling of more saline water along the southern coast of Cornwallis Island because of the Coriolis effect. Under these conditions there is net southerly transport of cold, more saline water across Barrow Strait (Prinsenberg \& Bennett 1987). But in 1986, with much of Barrow Strait ice free, meterological events apparently caused a breakdown in upwelling circulation, current reversals and intrusions of less saline water from the south into the Resolute Passage area persisting for at least $2 \mathrm{wk}$ (Bedo et al. 1990). Transects across adjacent Barrow Strait have shown differences in the zooplankton composition on opposite sides (H. E. Welch unpubl.), presumably related to differences between water masses. Major changes in the distribution of these different water masses could produce different estimates of total abundance and/or composition in Resolute Passage. A significant change in water properties, including change in population structure of Pseudocalanus acuspes, occurred in mid May 1986 (Bedo et al. 1990), which might also have influenced the ctenophore population (Fig. 2). On the other hand, we believe that the overall pattern of population development in Mertensia ovum in the Resolute Passage largely reflects biological dynamics, for the following reasons: first, no large-scale changes in population concentrations or composition were observed when sampling at the same depth on consecutive days, even with a change in current direction; and second, a regular progression of ctenophore size classes from adult to eggs to adult was observed during the study. If different water masses were being sampled, then at least $M$. orum in the same developmental stages were occurring simultaneously in all water masses.

The factor most often cited as affecting the seasonal abundance of gelatinous predators is prey abundance (Greve 1971, Kremer 1976, Larson 1986a). Condition has been shown to be an important factor in the timing of their egg production (Larson 1986b). In Resolute Passage, there would seem to be sufficient large prey in the water column over winter to support predator populations (Conover unpubl.). In the case of Mertensia ovum, it is in condition to spawn just as its prey begins to spawn. Hence, small ctenophores are present in the water column when small prey are most abundant. In early spring under the ice of Resolute Passage, copepod nauplii increase by 2 orders of magnitude between April and June (Conover \& Harris unpubl.). Microzooplankton are required by larval ctenophores for efficient growth (Stoecker et al. 1987). The 'catchability' (ratio of capture per encounter) of prey has been shown to be an inverse function of prey size in other gelatinous predators (Greve 1977, Bailey \& Batty 1983, 1984, Greene 1986, Greene et al. 1986,
Purcell et al. 1987). Preliminary observations indicate that this relationship also holds for $M$. ovum (Siferd unpubl.). The strategy would ensure that young ctenophores are present when both the encounter rate and catchability are optimized.

The factor most often associated with the decline of a population of gelatinous predators is predation. Greve $\&$ Reiners (1988) demonstrated a linked, negative feedback loop between the seasonal peaks of Pleurobrachia pileus and their predators Beroe gracilis. In Narragansett Bay (Rhode Island, USA), the seasonally abundant butterfish was a major factor responsible for the decline of Mnemiopsis leidyi (Kremer 1976, Kremer \& Nixon 1976). A second predator, Beroe ovata, although only sporadically abundant in that Bay, also had a clearly negative influence on $M$. leidyi when present.

Species of Beroe have been found to feed exclusively on gelatinous zooplankton and may specialize on a particular prey species (Purcell 1991). Contrasting views have been expressed in the literature about feeding of Beroe cucumis. Greve (1970) found that $B$. cucumis only fed on Bolinopsis infundibulum, while a second species, Beroe ovata, only fed on Pleurobrachia pileus. Anderson (1974) found that B. cucumis fed on either $P$. pileus or Bolinopsis infundibulum in aquaria. Swanberg (1974) reported that Beroe cucumis would eat any ctenophore contacted. In Resolute Passage, B. cucumis are much more abundant than Bolinopsis infundibulum, which could then hardly be the only prey source as suggested by Greve (1970). The parallel population abundances of Mertensia ovum and Beroe cucumis suggest that they might have a predator-prey relationship. Indeed, B. cucumis does feed on $M$. ovum by ingesting whole individuals (Siferd pers. obs.), but the extent of feeding has not been quantified.

Our data indicate that Beroe cucumis abundance peaked when Mertensia ovum did, which is not the normal pattern in a predator-prey relationship. Greve \& Reiners (1988) showed the Beroe gracilis population to lag behind that of their prey, Pleurobrachia pileus, by ca 4 to $5 \mathrm{wk}$. It may also be that $B$. cucumis is not a specialized a predator like $B$. gracilis (Greve \& Reiners 1988). There are Bolinopsis infundibulum, Cyanea capillata and a number of hydromedusae available in Resolute Passage which B. cucumis could potentially consume. Therefore their numbers would not be totally dependant on the availability of $M$. ovum.

Other predators known to feed on Mertensia ovum, thereby possibly influencing its population levels, include the scyphozoan Cyanea capillata (Purcell 1991, Siferd pers. obs.) and arctic cod Boreogadus saidi (H. Hop pers. comm.). Two avian predators which are known to feed on gelatinous zooplankton are the 
northern fulmar Fulmarus glacialis and black-legged kittiwake Rissa tridactyla (Harrison 1984), both common in the Resolute area.

\section{Mertensia ovum age classes}

Following cohorts of gelatinous zooplankton in field populations has proved difficult (Reeve \& Walter 1978). Many reasons exist, including rapid growth when food is optimal (Hirota 1974, Larson 1986a). When food is limiting, gelatinous zooplankton reduce their metabolism (Percy 1988) and survive by 'degrowth', using internal reserves and actually shrinking in size (Hamner \& Jenssen 1974, Kremer 1976). Differential changes in size between cohorts distort the sizefrequency distribution making cohorts virtually impossible to distinguish.

The 6 April 1986 sample of Mertensia ovum represented an overwintering population before spawning began. The presence of 3 groups with distinctly different lipofuscin levels suggests that $M$. ovum can survive for least 3 yr. Percy (1989) predicted that this might be the case from size-frequency data, reasoning '...that Mertensia may be similar to other arctic planktonic organisms that live for 2 or more years...' Even though the 8 June 1986 sample contained only 2 age classes, a 3 yr life span for $M$. ovum is not precluded. In this sample, young of the year ( $<3 \mathrm{~mm}$ polar length) were not available for lipofuscin assay, but by June, the oldest group may have spawned and died off.

The fact that ctenophores undergo degrowth when food is limiting presents a potential problem when trying to age populations by either size-frequency or lipofuscin analysis. The basic premise of the age-pigment technique that lipofuscin is accumulated in the cells, and not metabolized during cell shrinkage (Sohal 1981. Wolman 1981), may not be supported in ctenophores where degrowth is related to a decrease not only in cell size but also in number (Hamner \& Jenssen 1974). What happens to the lipofuscin in a cell when the cell is resorbed is not known, but presumably cell contents, including age-pigments, are redistributed to the remainder.

If lipofuscin is indeed lost during degrowth, the ageing based on lipofuscin analysis would not be reliable. Ctenophore degrowth itself makes ageing through size-frequency analysis very questionable. That 3 frequency modes were shown in one of the samples using the lipofuscin technique would suggest some promise for this method of ageing. Our lipofuscin results are at least partial confirmation of Percy's (1989) supposition of a multi-year life cycle for Mertensia ovum. Obviously, more controlled research is required to validate the lipofuscin technique for ageing ctenophores and gelatinous zooplankton in general.

\section{Digestion rate}

Mertensia ovum seem to have a metabolism suited to the pulsed food supply and strong seasonality of the Arctic (Percy 1988). Because their metabolic rate was lower than ctenophores from the tropical and temperate regions (Percy 1988), their digestion rate might also have been slower. However, digestion rates for $M$. ovum were comparable to those for Pleurobrachia bachei from Saanich Inlet, British Columbia, Canada (Larson 1987b), even though the experimental temperatures in Resolute Passage were 10 to $12{ }^{\circ} \mathrm{C}$ colder. Kremer et al. (1986) found that Bolinopsis vitrea, a lobate ctenophore, digested 200 to $330 \mu \mathrm{m}$ copepods in $1.9 \mathrm{~h}$. Water temperature was not reported, except that the experiments were conducted in warm Florida waters. On similar sized prey, $M$. ovum had a digestion rate of $2 \mathrm{~h}$. Apparently, $M$. ovum have digestive enzymes that can digest prey rapidly even at low temperatures.

Cold adaptation for enzymes regulating intermediary metabolism has been demonstrated for polar fish (Clarke 1991). One mechanism would be to increase the amount of enzyme when needed, as shown for digestive enzymes in cold water zooplankton on several occasions, but usually in response to increased food (Head \& Conover 1983, Båmstedt 1988, Hirche 1989). The only published data on digestive enzymes in ctenophores, in this case for Pleurobrachia pileus at $15^{\circ} \mathrm{C}$ (Hoeger \& Mommsen 1984), suggest a modest $1<2$ times increase with feeding for several enzymes followed by a decrease to near starting levels after 64 h. A few measurements of digestive enzymes have been made on Mertensia ovum from Resolute Passage for protease, averaging $6.4 \mu \mathrm{g}$ substrate $\mathrm{min}^{-1}$ ( $\mathrm{mg}$ protein) $)^{-1}$ at less than $0^{\circ} \mathrm{C}$ (Siferd unpubl.). The comparable mean for $P$. pileus was $10.8 \mu \mathrm{g} \mathrm{S} \mathrm{min}^{-1} \mathrm{mg}^{-1}$, but the range was large $\left(1.5\right.$ to $\left.53.4 \mu \mathrm{g} \mathrm{S} \mathrm{min}^{-1} \mathrm{mg}^{-1}\right)$ and incorporated that for $M$. ovum. Without further experimentation it is impossible to more completely evaluate digestive performance by $M$. ovum

One potential source of error in our digestion rates could be the higher $\left(\leq 1.5^{\circ} \mathrm{C}\right)$ temperature in the experimental aquaria over that in situ, which might result in higher metabolism and more rapid digestion of prey. However, the experimental temperature falls within range of summer surface-water temperature in Resolute Passage. Therefore, the digestion rates reported here may be too fast for winter, but are probably within the range for summer when most growth occurs. A second source of error is that digestion time was defined as the point at which the digestible copepod tissue had been absorbed by the ctenophore and only an extremely disarticulated indigestible exoskeleton remained. The time of gut evacuation was not 
recorded. Gut evacuation time, if used in the ingestion equation, would yield lower ingestion rates.

\section{Impact of Mertensia ovum on other zooplankton}

Mertensia ovum was found to be an opportunistic feeder, concentrating on 4 species, Pseudocalanus acuspes, Calanus glacialis, C. hyperboreus and Parathemisto libellula. It also took advantage of barnacle nauplii when they were abundant in 1986 (Table 1). From the population data for both predator and prey, and the digestion rate of $M$. ovum, the potential impact of feeding $M$. ovum on prey populations can be assessed. Using yearly means for daily ration, $M$. ovum might consume $9.3 \%$ of the large copepod population, $2.8 \%$ of the medium and $3.8 \%$ of the small, but could consume up to $45.4 \%$ for the large, $20.1 \%$ of the medium and $20.7 \%$ of the small prey population (prey densities from Conover \& Harris unpubl.). Impact would be lower in January when the ctenophore population is low and much higher in the summer at peak population levels. The daily population ingestion rates for $M$. ovum from Resolute Passage are slightly higher than those determined from a population model for M. ovum from the Barents Sea (Swanberg \& Bámstedt 1991), which is not surprising since Resolute Passage had a much higher population level than the one modelled.

Mertensia ovum therefore controls to some extent the transfer of energy through the arctic food web through direct competition for food with or by predation on other members. It potentially competes with, and possibly consumes arctic cod Boreogadus saida, the key food-web intermediate in the transfer of energy from lower trophic levels to marine mammals in the arctic food web (Welch et al. in press). Indeed, the diet of $M$. ovum overlaps almost completely with that of arctic cod, especially young of the year (Bradstreet et al. 1986, Lonne \& Gulliksen 1989), so the presence of large numbers could significantly affect year class strength. We conclude that in the Arctic as elsewhere gelatinous predators can be an important regulator in the food web.

Acknowledgements. We thank L. Harris, J. Anning, M. Curtis, D. Pike, P. Amarualik and M. Bergmann for their assistance in the field. We thank A. Bedo for examining Mertensia ovum for digestive enzymes. Partial financial support for this project was supplied by a Natural Sciences and Engineering Council Operating Grant \#0GP0002979 to R.J.C. Logistic support was provided by the Polar Continental Shelf Project. Many thanks must be given to the entire crew of Polar Shelf for their help during this project. A special thanks goes to all the people of DFO South Camp for their generous help and allowing T.D.S. into their camp during the summers of 1985 and 1986 . K. A. Martin, H. E. Welch, K. L. Young, G. I. Matsumoto and 3 anonymous reviewers made suggestions for improving the manuscript.

\section{LITERATURE CITED}

Anderson, E. (1974). Trophic interactions among ctenophores and copepods in St. Margaret's Bay, Nova Scotia. Ph.D. thesis, Dalhousie University, Halifax

Bailey, K. M., Batty, R. S. (1983). A laboratory study of predation by Aurelia aurita on larval herring (Clupea harengus): experimental observations compared with model predictions. Mar. Biol. 72: 295-301

Bailey, K. M., Batty, R. S. (1984). Laboratory study of predation by Aurelia aurita on larvae of cod, flounder, plaice and herring: development and vulnerability to capture. Mar. Biol. 83: 287-291

Bajkov, A. B. (1935). How to estimate the daily natural food consumption of fish under natural conditions. Trans. Am. Fish. Soc. 65: 288-289

Båmstedt, U. (1988). Interspecific, seasonal and diel variations in zooplankton trypsin and amylase activities in Kosterfjorden, western Sweden. Mar. Ecol. Prog. Ser. 44: $15-24$

Bedo, A. W., Head, E. J. H., Conover, R. J., Horne, E. P. W., Harris, L. R. (1990). Physiological adaptations of an underice population of Pseudocalanus in Barrow Strait, N.W.T., to increasing food supply in spring. Polar Biol. 10:561-570

Bell, K. N. E. (1989). Grazing rates of Pleurobrachia pileus. M.Sc, thesis, Dalhousie University, Halifax

Biggs, D. C. (1977). Respiration and ammonium excretion by open ocean gelatinous zooplankton. Limnol. Oceanogr. 22: $108-117$

Bradstreet, M. S. W., Finley, K. J., Sekerak, A. D., Griffiths, W. B., Evans, C. R., Fabijan, M. F., Stallard, H. E. (1986). Aspects of the biology of arctic cod (Boreogadus saida) and its importance in arctic marine food chains. Can. Tech. Rep. Fish. Aquat. Sci. 1491

Clarke, A. (1991). What is cold adaptation and how should we measure it? Am. Zool. 31: 81-92

Ettershank, G. (1983). Age structure and cyclical annual size change in the Antarctic krill, Euphausia superba Dana. Polar Biol. 2: 189-193

Ettershank, G. (1984). A new approach to the assessment of longevity in the Antarctic krill Euphausia superba. J. crust. Biol. 4: 295-305

Greene, C. H. (1986). Patterns of prey selection: implications of predator foraging tactics. Am. Nat. 128:824-839

Greene, C. H., Landry, M. R., Monger, B. C. (1986). Foraging behavior and prey selection by the ambush entangling predator Pleurobrachia bachei. Ecology 67 1493-1501

Greve, W. (1970). Cultivation experiments on North Sea ctenophores. Helgoländer wiss. Meeresunters. 20: 304-317

Greve, W. (1971). Ökologishe Untersuchungen an Pleurobrachia pileus. 1 Freilanduntersuchungen. Helgoländer wiss. Meeresunters. 22: 303-325

Greve, W. (1977). Interspecific interaction: the analysis of complex structures in carnivorous zooplankton populations. Helgoländer wiss. Meeresunters. 30: 83-91

Greve, W., Reiners, F. (1988). Plankton time-space dynamics in German Bight - a systems approach. Oecologia 77 : $487-496$

Hamner, W. M., Jenssen, R. M. (1974). Growth, degrowth, and irreversible cell differentiation in Aurelia aurita. Am. Zool. 14: 833-849

Harding, J. P. (1949). The use of probability paper for the graphical analysis of polymodal frequency distributions. J. mar biol. Ass. U.K. 28: 141-153

Harrison, N. M. (1984). Predation on jellyfish and their associates by seabirds. Limnol. Oceanogr. 29: 1335-1337 
Head, E. J. H., Conover, R. J. (1983). Induction of digestive enzymes in Calanus hyperboreus. Mar. Biol. Lett. 4: $219-231$

Hirche, H.-J. (1989). Spatial distribution of digestive enzymes of Calanus finmarchicus and C. hyperboreus in Fram Strait/Greenland Sea. J. Plankton Res. 11: 431-443

Hirota, J. (1974). Quantitative natural history of Pleurobrachia bachei in La Jolla Bight. Fish. Bull. U.S. 72 295-335

Hoeger, U., Mommsen, T. P. (1984). Hydrolytic enzymes in the two North Sea ctenophores Pleurobrachia pileus and Beroe gracilis. Mar. Biol. 81: 123-130

Huntley, M., Strong, K. W., Dengler, A. T (1983). Dynamics and community structure of zooplankton in the Davis Strait and Northern Labrador Sea. Arctic 36: 143-161

Kremer, P. M. (1976). Population dynamics and ecological energetics of a pulsed zooplankton predator, the ctenophore Mnemiopsis leidyi. In: Wiley, M. (ed.) Estuarine processes, Vol. 1, Uses, stresses and adaptation to the estuary. Academic Press, New York, p. 197-215

Kremer, P. M., Nixon, S. (1976). Distribution and abundance of the ctenophore Mnemiopsis leidyi in Narragansett Bay. Estuar. coast. mar. Sci. 4:627-639

Kremer, P. M., Reeve, M. R., Syms, M. A. (1986). The nutri tional ecology of Bolinopsis vitrea: comparisons with Mnemiopsis mccradyi from the same region. J. Plankton Res. 8: 1197-1208

Larson, R. J. (1986a). Seasonal changes in the standing stocks, growth rates, and production rates of gelatinous predators in Saanich Inlet, British Columbia. Mar. Ecol Prog. Ser. 33: 89-98

Larson, R. J. (1986b). Ova production by hydromedusae from the NE Pacific. J. Plankton Res. 8: 995-1002

Larson, R. J. (1987a). Respiration and carbon turnover rates of medusae from the NE Pacific. Comp. Biochem. Physiol. 87A: $93-100$

Larson, R. J. (1987b). Daily ration and predation by medusae and ctenophores in Saanich Inlet, B.C., Canada. Neth. J. Sea Res. 21: 35-44

Lenne, O. J., Gulliksen, B. (1989). Size, age and diet of polar cod, Boreogadus saida (Lepechin 1773), in ice covered waters. Polar Biol. 9: 187-191

Moller, H. (1980). Scyphomedusae as predators and food competitors of larval fish. Meeresforsch. 28: 90-100

Nicol, S. (1987). Some limitations on the use of the lipofuscin ageing technique. Mar. Biol. 93: 609-614

Park, Y C., Carpenter, E. J. (1987). Ammonium regeneration and biomass of macrozooplankton and ctenophores in Great South Bay, New York. Estuaries 10: 316-320

Percy, J. A. (1988). Influence of season, size and temperature on the metabolism of an arctic cydippid ctenophore, Mertensia ovum (Fabricius). Sarsia 73: 61-70

Percy, J A. (1989). Abundance, biomass and size frequency of an arctic ctenophore, Mertensia ovum (Fabricius) from Frobisher Bay, Canada. Sarsia 74: 95-105

Percy, J. A., Fife, F. J. (1985). Energy distribution in an arctic macrozooplankton community. Arctic 38: 39-42

Pianka, H. D. (1974). Ctenophora. In: Giese, A. C., Pearse, J. S. (eds.) Reproduction of marine invertebrates, Vol. I,

This article was submitted to the editor
Aceolomate and pseudoceolomate metazoans. Academic Press, New York, p. 201-265

Prinsenberg, S. J., Bennett, E. B. (1987). Mixing and transports in Barrow Strait, the central part of the Northwest Passage. Cont. Shelf Res. 7: 913-935

Prinsenberg, S. J., Bennett, E. B. (1989). Transport between Peel Sound and Barrow Strait in the Canadian Arctic. Cont. Shelf Res. 9: 427-444

Purcell, J. E. (1991). A review of cnidarians and ctenophores feeding on competitors in the plankton. Hydrobiologia 216/217: 335-342

Purcell, J. E., Grover, J .J. (1990). Predation and food limitation as causes of mortality on larval herring at a spawning ground in British Columbia. Mar. Ecol. Prog. Ser. 59: $55-61$

Purcell, J. E., Siferd, T. D., Marliave, J. B. (1987). Vulnerability of larval herring (Clupea harengus pallasi) to capture by the jellyfish Aequorea victoria. Mar. Biol. 94: $157-162$

Reeve, M. R., Walter, M. A. (1978). Nutritional ecology of ctenophores - a review of recent research. Adv. mar. Biol. 15: 249-287

Reeve, M. R., Walter, M. A., Ikeda, T. (1978). Laboratory studies of ingestion and food utilization in lobate and tentaculate ctenophores. Limnol. Oceanogr. 23: 740-751

Schneider, G. (1987). Role of advection in the distribution and abundance of Pleurobrachia pileus in Kiel Bight. Mar. Ecol. Prog. Ser. 41: 99-102

Shushkina, E. A., Musayeva, E. I. (1983). The role of jellyfish in the energy system of Black Sea plankton communities. Oceanology 23: 92-96

Siferd, T. D., Conover, R. J. (1992). An opening-closing plankton net for horizontal sampling under polar sea-ice. Sarsia 76: $273-277$

Sohal, R. S. (1981). Metabolic rate, ageing and lipofuscin accumulation. In: Sohal, R.S. (ed.) Age pigments. EIsevier/North-Holland Biomedical Press, Amsterdam, p. $303-316$

Stoecker, D. K., Verity, P. G., Michaels, A. E., Davis, L. H. (1987). Feeding of larval and post-larval ctenophores on microzooplankton. J. Plankton Res. 9: 667-683

Swanberg, N. (1974). The feeding behavior of Beroe ovata. Mar. Biol. 24: $69-76$

Swanberg, N., Bảmstedt, U. (1991). The role of prey stratification in the predation pressure by the cydippid ctenophore Mertensia ovum in the Barents Sea. Hydrobiologia 216/217:343-349

van der Veer, H. W., Sadee, C. F. M. (1984). Seasonal distribution of the ctenophore Pleurobrachia pileus in the western Dutch Wadden Sea. Mar. Biol. 79: 219-227

Weich, H. E., Bergmann, M. A., Siferd, T D., MartinBergmann, K. A., Curtis, M. F., Crawford, R. E., Conover, R. J., Hop, H. (1n press). Energy flow through the marine environment of the Lancaster Sound region, arctic Canada. Arctic

Wolman, M. (1981). Factors affecting lipid pigment formation. In: Sohal, R. S. (ed.) Age pigments. Elsevier/North-Holland Biomedical Press, Amsterdam, p. $265-281$

Manuscript first received: January 2, 1992

Revised version accepted: July 28, 1992 